\title{
Judgment of the General Court of the EU on Access to Information under Substance Law
}

\author{
Case T-545/11, Judgment of 08 October 2013.
}

Horst von Holleben*

On 08 October 2013, the General Court of the European Union (hereinafter General Court) delivered a judgment based on the Aarhus Regulation 1367/2006 on the access to information on substances under plant protection law, which attracted considerable attention among experts with conflicting response from environmental associations and industry. The judgment - still appealable at the time this article was written - would in case of becoming unappealable result in extensive limitations to the protection of commercial and industrial secrets under plant protection law, but additionally also generally under substance law. The following article analyses the content of the decision. ${ }^{1}$

\section{Facts}

On 20 December 2010 the applicants, Stichting Greenpeace Nederland and Pesticide Action Network Europe (PAN Europe), requested from the European Commission access to several documents relating to the first authorisation for the placing of glyphosate on the market as an active substance, granted by the competent German authorities under Council Directive 91/414/EEC of 15 July 1991 concerning the placing of plant protection products on the market (OJ 1991 L 230, p. 1). The request was based on Regulation (EC) No 1049/2001 of the European Parliament and of the Council of 30 May 2001 regarding public access to European Parliament, Council and Commission documents ${ }^{2}$, and on Regulation (EC) No 1367/2006 of the European Parliament and of the Council of 6 September 2006 on the application of the provisions of the Aarhus Convention on Access to Information, Public Participation in Decision-making and Access to Justice in Environmental Matters to Community institutions and bodies. ${ }^{3}$

\footnotetext{
* Dr. Horst von Holleben is a Rechtsanwalt (Attorney at Law) in Bad Homburg.

1 Operative part of the judgment is available on the website of the Court of Justice of the EU at $<$ www.curia.europa.eu $>$. The German version of this case annotation is published in StoffR 6/2013. The English translation was produced with friendly support of the Verband der Chemischen Industrie e.V. ( $\mathrm{VCl}$, the German chemical industry association).

2 OJ 2001 L 145 p. 43, hereinafter Transparency Regulation.

3 OJ 2006 L 264 p. 13, hereinafter Aarhus Regulation.
}

After prior consultation with the German authorities, the Commission granted access to a number of requested documents. By decision of 10 August 2011, access was denied with regard to volume 4 of the draft assessment report of the German authorities (hereinafter: document at issue), which the German authorities refused to disclose and which included the complete list of all tests that had been submitted by the operators seeking the first inclusion of glyphosate in Annex I to Directive 91/414.

The Commission held that the information contained in the document at issue concerned the glyphosate production process of the operators which had sought the inclusion of glyphosate in Annex I of Directive 91/414. On balancing the various interests, the need to protect the intellectual property rights outweighed the public interest in disclosure of the information. In the Commission's view, disclosure of the information contained in the document at issue would allow competing undertakings to copy the production methods followed by the operators, which would considerably impair their commercial interests, infringe their intellectual property rights and lead to considerable loss for them. The public interest in disclosure of the information had already been taken into account, since the possible effects of glyphosate emissions were shown in other parts of the draft report that had already been disclosed to the public, in particular those concerning relevant impurities and metabolites. As regards the information relating to the non-relevant impurities that was included in the document at issue, the Commission considered it to relate to ele- 
ments which do not present risks to health or the environment, but which make it possible to reveal the manufacturing process of each product. The Commission concluded that the information requested did not relate to emissions into the environment within the meaning of Article 6(1) of Regulation No 1367/2006, and that there was no evidence of an overriding public interest in disclosure within the meaning of Regulation No 1049/2001, whereas such an interest lay in protecting the commercial interests and intellectual property rights of the glyphosate manufacturers.

The applicants claimed that the Court should annul the Commission's decision of 10 August 2011 for breach of the Aarhus Convention, the Transparency Regulation 1049/2001, and the Aarhus Regulation 1367/2006. They in particular stated that the exception from the right to access for protecting the commercial interests of a specific natural or legal person did not apply, as an overriding public interest justified the disclosure of the requested information relating to emissions into the environment.

Upon request by the Court, the Commission submitted the "document at issue" to the Court; the document was not communicated to the applicants. The "document at issue" consists of three sub-documents, which the operators involved had submitted for the authorisation of the placing on the market of the plant protection product, and which were marked as confidential.

In the course of the proceedings, the applicants withdrew the motion for disclosure of the studies on which the authorisation was based. Therefore, the Court also limited the subject matter of the dispute to a part of the "document at issue", as follows (paragraph 24): Information on the degree of purity of the active substance; information on the 'identity' and quantities of all the impurities present in the active substance; information on the analytical profile of the batches submitted by the operators for the tests; information on the exact composition of the plant protection product developed.

\section{Content of the decision}

\section{Annulment of the Commission's decision of 10 August 2013}

Corresponding to the limited subject matter of the dispute, the Court annulled the Commission's deci- sion of 10 August 2011, by which access to the "document at issue" had been denied, as far as it refused the applicants access to the information contained in the three sub-documents of the "document at issue", as set forth below:

- the identity and quantity of all the impurities in the active substance notified by each operator

- the impurities present in the various batches and the minimum, median and maximum quantities of each of those impurities

- the composition of the plant protection products developed by the operators (on the basis of the active substance).

The Commission was ordered to pay the costs.

\section{Scope of the right of access arising from Art. 6(1) sentence 1 of the Aarhus Regulation}

The Court held that the principle of the widest possible public access to the documents of the European Union's institutions on the basis of the Transparency Regulation 1049/2001 is subject to limitations. In the present case, the Commission had invoked the exception according to Art. 4(2), first indent, of the Transparency Regulation, according to which the institutions refuse access to a document whose disclosure "would impair the commercial interests of a natural or legal person, including intellectual property rights, unless there is an overriding public interest in the disclosure". The Commission had denied an overriding public interest.

The Court first found that such exceptions had to be interpreted and applied restrictively, since they deviate from the principle of the widest possible public access to documents (paragraph 32). Furthermore, the Court emphasised that with regard to applications for access to environmental information the Aarhus Regulation 1367/2006 applied, which in Art. 6(1) sentence 1 stated the irrebuttable presumption that an overriding public interest in disclosure existed when the requested information related to emissions into the environment. This meant that the relevant institution to which an application for access to a document was submitted would disclose the document even if such disclosure were liable to undermine the protection of the commercial interests of a particular natural or legal person, including that person's intellectual prop- 
erty, within the meaning of Article 4(2), first indent, of Regulation No 1049/2001 (paragraph 38).

In contrast, the provisions of Directive 91/414 for the protection of the confidentiality of information containing commercial and industrial secrets ${ }^{4}$ did not apply. It is stated in paragraph 40: "It suffices to note that the existence of such rules cannot rebut the irrebuttable presumption arising from Article 6(1) sentence 1 of Regulation No 1367/2006". The same applied to Art. 63(2) of Regulation (EC) No 1107/2009 of 21 October 2009. ${ }^{5}$ It is stated in paragraph 41: "That provision merely refers to the overriding public interest protected by Article 4(2), first indent, of Regulation No 1049/2001, over which the overriding public interest referred to in the first sentence of Article 6(1) of Regulation No 1367/2006 takes precedence."

The Court denies the Commission's view that it is necessary to ensure that the Transparency Regulation and the Aarhus Regulation are interpreted consistently with Art. 16 and 17 of the Charter of Fundamental Rights, i.e. with the protection of the freedom to conduct a business and the right to property, and with Art. 39(2) and (3) of the Agreement on the Trade Related Aspects of Intellectual Property Rights (TRIPS). It is stated in paragraph 44:

"Nevertheless, it cannot be accepted that, for the purpose of ensuring a consistent interpretation of European Union law, the validity of a clear and unconditional provision of secondary legislation may be called into question (see, by analogy, Interseroh Scrap and Metal Trading, paragraphs 44 and 46). Under the pretext of ensuring a fair balance between the protection of the fundamental right to property, which encompasses intellectual prop-

4 Art. 14(1) of Directive 91/414 reads: "Member States and the Commission shall, without prejudice to Council Directive 90/313/EEC of 7 June 1990 on the freedom of access to information on the environment (OJ L 158 of 23 June 1990, p. 56), ensure that information submitted by applicants involving industrial and commercial secrets is treated as confidential if the applicant wishing to have an active substance included in Annex I or the applicant for authorization of a plant protection product so requests, and if the Member State or the Commission accepts that the applicant's request is warranted."

5 According to Art. 63(2) disclosure of specific information shall normally be deemed to undermine the protection of the commercial interests of the individuals concerned. This inter alia includes information on impurities of the active substance except for the impurities that are considered to be toxicologically, ecotoxicologically or environmentally relevant (Art. 63(2) lit. b)), but also information on the complete composition of a plant protection product (Art. 63(2) lit. f)).

6 Wording: "[...] that there is an overriding public interest in the disclosure if the requested information relates to emissions into the environment". erty rights, and the protection of other fundamental rights, the Commission seeks, by its line of argument, not to ensure a consistent and harmonious interpretation of Regulation No 1049/2001 and Regulation No 1367/2006 with the provisions of the Charter, of Directive 91/414 or of Regulation No 1107/2009, but to preclude the application of the first sentence of Article 6(1) of Regulation No 1367/2006. Such an approach cannot, in any event, be accepted, since it would amount to disapplying a clear and unconditional provision of a European Union regulation, which is not even claimed to be contrary to a superior rule of law."

\section{Notion of information relating to emissions into the environment}

The Commission had submitted that the notion of emissions was to be interpreted restrictively. The Court refused this, pointing out that exceptions to the access to documents had to be interpreted restrictively. Regarding Art. 6(1) sentence 1 Aarhus Regulation, it is stated in paragraph 51: "By providing that, where the information requested relates to emissions into the environment, an overriding public interest in disclosure exists which is superior to an interest protected by an exception, the first sentence of Article 6(1) of Regulation No 1367/2006 allows a specific implementation of that general principle [what is meant is the principle of the widest possible access to documents, author's note]". As stated in recital 15 of the Aarhus Regulation, only the grounds for refusal as regards access to environmental information should be interpreted in a restrictive way (paragraph 52). Somewhat surprising and without further explanation, the Court then in paragraph 53 interprets Art. 6(1) sentence 1 of the Aarhus Regulation ${ }^{6}$ as follows: "Accordingly, in order for the disclosure to be lawful, it suffices that the information requested relate in a sufficiently direct manner to emissions into the environment."

For interpreting Art. 6(1) sentence 1 Aarhus Regulation, the Commission had also invoked the Implementation Guide to the Aarhus Convention, published by the United Nation Economic Commission for Europe (UNECE) in 2000 (hereinafter: Implementation Guide), which for interpreting the notion of emission referred to the definition in Council Directive $96 / 61 / E C$, i.e. the direct or indirect release of sub- 
stances from installations. The Court held that according to the ruling of the European Court of Justice (ECJ), the Implementation Guide could not bindingly interpret the Convention and that neither the Aarhus Convention nor Regulation 1367/2006 restrict their respective scope of application to the consequences of industrial activities. It is stated in paragraph 56: "Therefore, the definition of emission into the environment which emerges from the Implementation Guide cannot be used to interpret Regulation No 1367/2006."

\section{Information contained in the "document at issue" in the opinion of the EU Court is information on emissions}

As "levelling rule" for the subsumption of the information in the "document at issue" according to Art. 6(1) sentence 1 Aarhus Regulation, the Court raises the question of "whether the document at issue contains information which relates, sufficiently directly, to emissions into the environment" (paragraph 57).

Regarding the impurities in the active substance, the Court fully agrees with the applicants' argumentation, paragraph 69:

"It must be pointed out that, as the applicants claim, a large part of the data in the sub-documents of which the document at issue is composed, referred to in paragraphs 66 to 68 above, concerns the identification and the quantity of various impurities present in the active substance notified by each of the operators which took part in the procedure for the inclusion of glyphosate in Annex I of Directive 91/414. Since the active substance must be included in a plant protection product, which, it is common ground, will be released into the air, principally by spraying, the 'identity' and the quantity of each impurity contained in such a substance constitutes information relating, in a sufficiently direct manner, to emissions into the environment, as the applicants rightly note (see paragraphs 62 and 63 above)."

The Court also agrees with the applicant's arguments on the analytical profile of the batches, paragraph 71: "As regards the analytical profile of batches tested, it must also be stated that the information concerning the quantity of all the impurities present in the var- ious lots and the minimum, median and maximum quantity of each of those impurities [...] constitutes, with the exception of the structural formulas of impurities set out in the summary tables in the second and third sub-documents, information relating, in a sufficiently direct manner, to emissions into the environment."

The Court holds that the same applies to the disclosure of the composition of plant protection products as requested by the applicants. It is stated in paragraph 73: "As regards the composition of plant protection products developed by the operators which applied for the inclusion of glyphosate in Annex I to Directive 91/414, it must be noted that the exact quantities, per kilogramme or per litre, of the active substance and of adjuvants used in their manufacture are indicated in part C.1.3, entitled 'Detailed specification of the preparations (Annex II A 1.4)' of the first sub-document and that such information relates in a sufficiently direct manner to emissions into the environment (see paragraph 69 above)."

In contrast, the methods of analysis and validation of the data do - in the Court's opinion - not constitute any information relating to emissions.

The Court dismissed the Commission's argumentation that all of the relevant information from a toxicological perspective and as regards the effect of the active substance on human health had been subject to a careful analysis and had been disclosed by the Commission decision of 6 May 2011. Likewise, the Court held that the Commission's submission that the applicants had not indicated the reasons why the documents which had already been disclosed did not suffice for assessing the validity of the process of the inclusion of glyphosate in Annex I to Directive 91/414 was irrelevant.

\section{Evaluation of the decision}

\section{Far-reaching implications of the - still appealable - decision}

The decision relates to plant protection law. It does, however, have implications on the entire area of substance law. Also all other substance-related laws contain provisions on the protection of commercial and industrial secrets, some of which - as in Art 63(2) of Regulation 1107/2009 - are endowed with special statutory protection against disclosure (e.g. 
Art. 118(2) REACH Regulation ${ }^{7}$, Art. 66(2) Biocidal Products Regulation). According to the Court's interpretation of Art. 6(1) sentence 1 of the Aarhus Regulation 1367/2006, such commercial and industrial secrets must be disclosed to a large extent.

At the time this comment on the judgment was written (early November 2013), the time limit for filing an appeal against the General Court's decision according to Art. 256(2) TFEU and the Statute of the Court had not yet expired. For the time being it needs to be left open whether the Commission and/or possibly other parties entitled to appeal file an appeal. As the Court's interpretation of Art. 6(1) sentence 1 of the Aarhus Regulation 1367/2006 fundamentally changes the previous legal practice of the authorities on public access to information submitted to them in the course of authorisation procedures, which frequently contain commercial and industrial secrets, and thus relates to fundamental questions, it would be desirable if the European Court of Justice (ECJ) clarified those questions.

\section{Previous court rulings on access to information on substances according to Aarhus ${ }^{8}$}

The General Court and the ECJ have already rendered a number of decisions on the first pillar of the Aarhus Convention "access to environmental information". As far as is known, however, the General Court's decision of 08 October 2013 in the legal case $\mathrm{T}-545 / 11$ is the first that applies Art. 6(1) sentence 1 of Aarhus

7 This provision and its interpretation in consideration of Aarhus is, inter alia, the subject matter of the still pending legal dispute Case T-245/11.

8 Good overview at Garcon, Access to environmental information versus protection of confidential business information, Recent case-law of the CJEU and of administrative courts in Germany, EurUP 2/2013 p. 100.

9 Insofar identical with Art. 6(1) sentence 1 Aarhus Regulation.

10 Cf. v. Holleben/Scheidmann, Öffentlicher Zugang zu Stoffinformationen nach REACH im Licht der Aarhus-Konvention IPublic access to information on substances according to REACH in the light of the Aarhus Convention], StoffR 6/2011 p. 237 (242); Kaus, The term "emission" in the domain of freedom of access to information, EurUP 6/2011 S. 293; Garcon, Access to environmental information versus protection of confidential business information, Recent case-law of the CJEU and of administrative courts in Germany, EurUP 2/2013 p. 100 (105-108); Garcon, Aarhus and Agrochemicals: The scope and limitations of access rights In Europe, EurUP 2012 p. 725 (7).

11 Data relating to the names of the owners of transferred accounts and of receiving accounts for transactions with emission certificates, certificates or Kyoto units relating to these transactions and their date and time of day.
Regulation 1367/2006 in substance law, according to which information relating to emissions into the environment must be disclosed without weighing the interests involved, even if they contain commercial and industrial secrets.

In its decision of 16 December 2010 (C-266/o9), the Court of Justice decided that information on residues of plant protection products constitute "environmental information" within the meaning of Directive 2003/4. However, the Court of Justice did apparently not follow the Advocate General's opinion that such information was information on "emissions into the environment" within the meaning of Art. 4(2) lit. $\mathrm{d}$ of Directive 2003/4. ${ }^{9}$ This conclusion is allowed because the Court of Justice denied the reopening of the oral hearing on the interpretation of Directive 2003/4 as set forth by the Advocate General, pointing out that it could also answer the question raised by the national court without discussing the Advocate General's point of view. The Court of Justice answered the question of the national court to the effect that the balancing of conflicting rights as prescribed by Directive 2003/4 had to be made in each individual case and could not be anticipated by national regulations. Such balancing of conflicting rights would have been irrelevant had the Court of Justice agreed with the Advocate General's interpretation of Art. 4(2) sentence 4 of Directive 2003/4. ${ }^{10}$

In its decision of 22 December 2010 (C-524/09), the Court of Justice affirmed the legislator's decision to allocate access to so-called "trading data"11 exclusively to the specific rules on publication and confidentiality of Directive 2003/87, and not to the rules of Directive 2003/04. It therefore denied the application of Directive 2003/4 in this case, even though those "trading data" were undisputedly seen as "environmental information". Thus, the Court of Justice did not arrive at the question raised by the national court, namely whether or not those data are to be considered information on "emissions into the environment" within the meaning of Art. 4(2) sentence 4 of Directive 2003/4. In contrast, the Advocate General Ms. Kokott held that Directive 2003/4 applied, and therefore had to address the issue of whether or not those data are to be considered information on "emissions into the environment" within the meaning of Art. 4(2) sentence 4 of Directive 2003/4. She then concluded that those data were in fact "environmental information", but not information on "emissions into the environment". While the notion of "environmental informa- 
tion" also included indirect information on emissions, information on "emissions into the environment" within the meaning of the irrebuttable presumption only referred to information on released substances. Emission allowance trading, however, took place before substances were released, therefore information in this respect was not information on emissions. ${ }^{12}$

German courts made decisions on the notion of "emissions into the environment". Thus, the German Federal Administrative Court (BVwG) in its decision of 24 September 2009 (7 C 2.09) ${ }^{13}$ on the interpretation of Section 9 (1) sentence 2 Environmental Information Act (UIG), which implements Art. 4(2) sentence 4 of Directive 2003/4, held that a restrictive interpretation of the notion "environmental information on emissions" was required and had to be limited to emissions from industrial plants which were actually emitted into the environment. The BVwG held that this interpretation was so obviously required that it did not consider it necessary to refer the case to the European Court in the preliminary ruling.

The Administrative Court Braunschweig even more clearly affirmed the BVwG's view in its - final and non-appealable - decision of 12 December 2012 $(2 \mathrm{~A} 1033712)^{14}$. This decision of the Administrative Court Braunschweig is of particular interest because - as in the case of the EU Court in T-545/11 - it does not only relate to the active substance glyphosate, but also to the "document at issue" of the EU Court (volume 4 of the draft report of the German authority as rapporteur) in this matter. Thus, the applicants sought disclosure of the "document at issue" both at a national and European level. The Administrative Court denied disclosure of the "document at issue", because - in stark contrast to the EU Court in T-545/11 - it did not consider the information contained therein to be "environmental information on emissions" within the meaning of Section 9 (1) sentence 2 UIG (or Art. 4(2) sentence 4 of Directive 2003/4).

\section{3. "Environmental Information" as requirement for the applicability of the Aarhus Regulation}

The application of Aarhus Regulation 1367/2006 requires that the requested information - here contained in the "document at issue" - is to be seen as "environmental information" within the meaning of Art. 2(1) lit. $\mathrm{d}$ of the Regulation. It is to be noted that the Court did not examine this question. Apparently it considered this requirement for the application of the Aarhus Regulation as so self-evident that it did not even have to be mentioned. The Court of Justice in its decision C-266/og did not so lightly deal with this question, and with regard to information on residues of plant protection products affirmed the classification as "environmental information" only after careful review. Thus, the view "information on chemicals is environmental information" so often held by environmental organisations is not shared by the ECJ. By no means is all information of the dossier for the classification of active substances in Annex I of Directive 91/414 "environmental information" within the meaning of the Aarhus Regulation, but those which deal with identifying harmful effects on human beings or the environment. It is at any rate certain that this question can be clarified only on a case-to-case basis. In this respect, consistent court ruling indicates that the notion "environmental information" is to be widely construed.

In the decision cited in III. 2, the Administrative Court Braunschweig considered the information in the "document at issue" as being "environmental information". Although doubts may be justified with regard to some of this information - this for instance relates to information on the complete composition of the plant protection products produced on the basis of glyphosate - this question shall not be further analysed here. However, it would have to be analysed in more detail if an appeal were filed against the decision of the General Court in the matter T-545/11.

\section{As to the interpretation of Art. 6(1) sentence 1 Aarhus Regulation}

\section{a) Interrelation: Transparency Regulation and Aarhus Regulation}

Based on the principle of the widest possible access to information, the Court stipulated that exceptions have to be interpreted restrictively. This can be regard-

12 Opinion in Case C-524/09 paragraph 69-74.

13 BVerwGE 135, 34

14 http://www.verwaltungsgericht-braunschweig.niedersachsen.de/ portal/live.php?navigation_id=25368\&_psmand=124 (last accessed on 13 Nov. 2013). The decision is described in Garcon, Access to environmental information versus protection of confidential business information, Recent case-law of the CJEU and of administrative courts in Germany, EurUP 2/2013 p. 100 (117, 118). 
ed as undisputed. The exceptions include Art. 4(2), first indent, of the Transparency Regulation, according to which the institutions refuse access to a document whose disclosure "would impair the commercial interests of a natural or legal person, including intellectual property rights, unless there is a public interest in the disclosure". According thereto it is undisputed that also commercial and industrial secrets are protected, unless public interest in the disclosure prevails. The provision of Art. 4(2), first indent, of the Transparency Regulation applies according to Art. 3 of the Aarhus Regulation if "environmental information" has been requested. However, Art. 4(2), first (and third) indent, of the Transparency Regulation is specifically interpreted in Art. 6(1) sentence 1 of the Aarhus Regulation to the effect that "overriding public interest in disclosure is given when the requested information relates to emissions into the environment." In this provision, the Court sees an irrebuttable statutory presumption. If such presumption is given, a balancing of conflicting rights is waived. Commercial and industrial secrets are disclosed without further balancing of conflicting rights. ${ }^{15}$

The described interrelation between the Transparency Regulation and the Aarhus Regulation is undisputed. The definition of the notion "emission into the environment", however, is controversial (see more details below).

b) Protection of commercial and industrial secrets in sectoral laws as compared to the Transparency Regulation and the Aarhus Regulation.

As set out in II. 2 above, the Court granted neither the statutory protection provisions set forth in Art. 14 of Directive 91/414 nor those in Art. 63(2) of Direc-

15 According to Art. 4(2) sentence 4 of Directive 2003/4 this does not apply to the protection of intellectual property. Thus, intellectual property can be disclosed only in case an overriding public interest in disclosure is stated.

16 See footnote 4.

17 The information specified therein cannot be kept secret.

18 In Case C-266/09 the ECJ applies Directive 2003/4, which replaced Directive 90/313 with effect as from 14 Feb. 2005. The ECJ also declared that Directive 91/414 can be applied only in consideration of Directive 2003/4 (paragraph 54).

19 This formulation is also found in Art. 118(2) REACH Regulation and in Art. 66(2) Biocidal Products Regulation. It links to Art. 4(2) first indent, Transparency Regulation with the consequence that its requirements no longer need to be substantiated and proven. The legislator has already rendered this performance. tive $1107 / 2009$ any legal effect with respect to the irrebuttable presumption of Art. 6(1) sentence 1 Aarhus Regulation.

According to Art. 14 of Directive 91/414 ${ }^{16}$, a commercial and industrial secret contained in the documents for the inclusion of an active substance, is kept secret only if the Commission or the Member State agrees to an application for maintenance of secrecy. In the present case, the German authorities as rapporteur agreed to maintain secrecy of the information contained in the "document at issue" (the requested information were not subject to Art. 14(2) of Directive $91 / 414)^{17}$ and therefore finally refused the disclosure requested by the applicants - as shown in the judgment of the Administrative Court Braunschweig referred to above. Likewise, the Commission dealing with the application for access in parallel also denied disclosure, without being able to identify any overriding public interest in the disclosure, nor any information on "emissions into the environment".

The Court's disregard of the regulation provided by the legislator in Article 14 of Directive 91/414 for the publication of data and their confidentiality with regard to the irrebuttable presumption of Art. 6(1) sentence 1 of the Aarhus Regulation meets with considerable reservations. Art. 14(1) of Directive 91/414 contains the reservation "without prejudice to Directive 90/313 of the Council of 7 June 1990"18, thus also including the irrebuttable presumption of Art. 4(2) sentence 4 of Directive 2003/4, which as Art. 6(1) sentence 1 of the Aarhus Regulation demands disclosure without balancing of conflicting interests in case of information on emissions into the environment. But such reservation cannot as a consequence invalidate the protection against disclosure set forth in Art. 14(1) of Directive $91 / 414$ by a wide interpretation of the notion "emissions into the environment". That would be a contradictory legal situation. An interpretation of Art. 4(2) Sentence 4 of Directive 2003/4 or of Art. 6(1) sentence 1 of the Aarhus Regulation which turns the special exception into a rule is incompatible with the conception of Art. 14 of Directive 91/414.

This evaluation becomes even more evident upon application of Regulation (EC) No 1107/2009, which replaced Directive 91/414 with effect as from 14 June 2011. According to Art. 63(2) of this Regulation, in respect of specific information "disclosure shall normally be deemed to affect the protection of the commercial interests or of privacy and the integrity of the individuals concerned". ${ }^{19}$ The specifically pro- 
tected information inter alia includes specifications of impurities of the active substance except for the impurities that are considered to be toxicologically, ecotoxicologically or environmentally relevant (Art. 63(2) lit. b)), results of production batches of the active substance including impurities (Art. 63(2) lit. c)), information on the complete composition of a plant protection product (Art. 63(2) lit. f)). In essence, this is the information contained in the "document at issue", disclosure of which the Court in its judgment in the case $\mathrm{T}-545 / 11$ ordered the Commission to provide, referring to the irrebuttable presumption of Art. 6(1) sentence 1 Aarhus Regulation.

It is true that Art. 63(2) Regulation 1107/2009 is subject to the Aarhus legislation. ${ }^{20}$ However, the special interpretation of Art. 6(1) sentence 1 Aarhus Regulation which the Court made in Case T-545/11 renders the legislator's decision on the specific protection of the information listed in Art. 63(2) Regulation 1107/2009 inapplicable. Such result, which in itself is contradictory, is unacceptable. The recent sectoral legislation on substance law (Plant Protection Regulation 1107/2009, Biocidal Products Directive, REACH Regulation) did in knowledge of the Aarhus Convention, Directive 2003/4 and the Aarhus Regulation create detailed provisions on the protection of commercial and industrial secrets, thereby presuming that these protective provisions were applicable and would not be annulled by the irrebuttable presumption in Art. 6(1) sentence 1 Aarhus Regulation or in Art. $4(2)$ sentence 4 Directive 2003/4. ${ }^{21}$

Consequently, the provision of Art. 6(1) sentence 1 Aarhus regulation must be interpreted to the effect that Art. 63(2) Regulation 1107/09 remains applicable. The reservation of the Aarhus legislation in Art. 63(3) Regulation 1107/09 therefore means that the European Union's institutions deny disclosure of the information specified in Art. 63(2) Regulation 1107/09 according to Art. 3 Aarhus Regulation in conjunction with Art. 4(2) Transparency Regulation, unless there is an overriding public interest in the disclosure. $^{22}$ This already constitutes a clear limitation of the protection of the information according to Art. 63(2) Regulation 1107/2009. The irrebuttable presumption of Art. 6(1) sentence 1 Aarhus Regulation, however, cannot refer to the information set forth in Art. 63(2) Regulation 1107/09, but - after examination of the individual case - at best to information that by special act is treated as confidential according to Art. 63(1) Regulation 1107/o9.
The ECJ decision of 22 December 2010 in Case C $524 / 11$ cited in III.2 above can also be invoked for this interpretation. In that decision, the ECJ approved the legislator's decision to allocate access to specific information in the area of trading with emission rights exclusively to the specific rules on publication and confidentiality of Directive 2003/87, and not to the rules of Directive 2003/04. ${ }^{23}$ It therefore denied the application of Directive 2003/4 in this case, even though those "trading data" were undisputedly seen as "environmental information". In accordance with this decision, the provisions of Regulation 1107/09 cannot be entirely excluded from the scope of application of the Aarhus Regulation, especially as Art. 63(3) Regulation 1107/09 contains the reservation of the Aarhus Directive 2003/4. ${ }^{24}$ With regard to the irrebuttable presumption of Art. 6(1) sentence 1 Aarhus Regulation, however, the ECJ's concept in Case C-524/11 can be transferred. Art. 63(2) of Regulation 1107/09 is lex specialis towards the general provision of Art. 6(1) sentence 1 Aarhus Regulation, with the result that the irrebuttable presumption does not apply to the information specified therein.

In the area of merger control, the ECJ in its decision of 28 June 2012 (C-477/10 P) held that the interpretation of the Transparency Regulation must pay due regard to the statutory system of merger law for the publication of data and their confidentiality. The balance which the Union legislature ensured in the EC merger regulation between the obligation on undertakings to communicate possibly sensitive commercial information to the Commission on the one hand, and the guarantee of increased protection of the information within the scope of professional and business secrecy on the other hand must not be jeopardised (paragraph 62 of decision C-477/10). This

20 Art. 63(3) of Regulation 1107/2009 states this expressly for the application in the Member States (Directive 2003/4). For application at a European level, Regulation 1367/2006 applies directly, also without explicit reservation.

21 As far as is known, the risk of erosion of protection by a wider interpretation of the notion "emissions into the environment" were not even discussed in the legislation procedures of the more recent substance laws. The legislation materials might have to be reviewed in this respect, if necessary.

22 Garcon, EurUP 2/2013 p. 100 (107) considers Art. 63(2) Regulation $1107 / 2009$ as lex specialis towards the Aarhus legislation and requests a reversal of the burden of proof to the effect that an overriding public interest in disclosure must be made evident.

23 Here, the ECJ did not cite the principle lex specialis derogat legi generali but nonetheless applied it.

24 See in this respect footnote 20. 
court ruling can be applied to the relationship between the provision in Art. 63 Regulation 1107/2009 and the Transparency Regulation and Aarhus Regu lation, because authorisation procedures according to substance law also require the transmission of sensitive data to the authorities, which principally have to guarantee the protection of such data.

\section{c) "Interpretation" of Art. 6(1) sentence 1 Aarhus Regulation in conformity with primary law}

As outlined in detail in II.2 above, the Court further refused to interpret the Transparency Regulation and the Aarhus Regulation in conformity with Art. 16 and 17 of the Charter of Fundamental Rights and with Art. 39(2) of the Agreement on the Trade Related Aspects of Intellectual Property Rights (TRIPS). ${ }^{25}$ In truth, so the Court, the inapplicability of Art. 6(1) sentence 1 Aarhus Regulation - a clear and unconditional regulation of Union law - shall be established under the "guise" of this argumentation.

The General Court's arguments are surprising. The general applicability of Art. 6(1) sentence 1 Aarhus Regulation is not questioned. Rather, the question is whether the European primary law (TFEU and Charter of Fundamental Rights) and an internationally binding treaty such as TRIPS ${ }^{26}$ require an interpretation of this regulation that complies with the commercial and industrial secrets protected under primary law and TRIPS. In this respect it has to be considered that also the Aarhus Convention and the Aarhus Regulation want to ensure the protection of commercial and industrial secrets. They do, however, require a restrictive interpretation of the exceptions in the Transparency Regulation and thus also of the notion of commercial and industrial secrets ${ }^{27}$, and in addition request disclosure of information containing commercial and industrial secrets if an overriding public interest is discernible. If then in case of infor-

25 In the German legal terminology the notion "verfassungskonforme Auslegung" is common.

26 The EU Court correctly says that the TRIPS Agreement is an integral component of Union Law and, although not directly applicable, should to the greatest possible extent be considered upon interpreting secondary laws (paragraph 45).

27 The Court did not question that the information contained in the "document at issue" related to commercial and industrial secrets.

28 Opinion of the Advocate General Ms. Kokott in Case C-524/09 paragraph 71.

29 Opinion of the Advocate General Ms. Kokott in Case C-524/09 paragraph 72,73 . mation on "emissions into the environment" according to Art. 6(1) sentence 1 Aarhus Regulation the protection of commercial and industrial secrets required under primary law and international law shall be eliminated completely, then that does in fact require a very specific justification. This results in the call for a restrictive interpretation of the notion "emissions into the environment".

\section{d) Notion "emissions into the environment" according to Art. 6(1) sentence 1 Aarhus Regulation}

The Court refuses a restrictive interpretation of the notion "emissions into the environment". According to the opinion of the Court, the principle of widest possible access to environmental information also and in particular extends to information on "emissions into the environment". It is stated in paragraph 53: "Accordingly, in order for the disclosure to be lawful, it suffices that the information requested relates in a sufficiently direct manner to emissions into the environment."

The notion "emissions into the environment" within the meaning of Art. 6(1) sentence 1 Aarhus Regulation is neither defined in the Aarhus Regulation nor in the Convention. The notion is also contained in the definition of "environmental information" in Art. 2(1) lit. d) of the Regulation, according to which "environmental information" means, inter alia: "information [...] on factors such as [...] emissions, discharges and other releases into the environment, affecting or likely to affect the elements of the environment as named in clause 1". "Information [...] on emissions" within the meaning of the definition of "environmental information" is thus not equal to "[...] information relating to emissions into the environment" within the meaning of Art. 6(1) sentence 1 Aarhus Regulation. The two provisions have different functions which preclude a uniform interpretation. ${ }^{28}$ The definition of a requested information as "environmental information" opens the scope of application of the Aarhus Regulation and only permits a meaningful balancing of the conflicting interests as to whether or not a particular information should be disclosed. In contrast, information "relating to emissions into the environment" within the meaning of Art. 6(1) sentence 1 Aarhus Regulation must always be disclosed without balancing of conflicting interests, even if they contain commercial and industrial secrets. ${ }^{29}$ 
The legislator of the Aarhus Regulation unfortunately failed to clearly work out this "quality leap" between the definition of "environmental information" and the irrebuttable presumption set forth in Art. 6(1) sentence 1; rather, it selected words that sound very similar or almost equal. This differentiation, however, clearly shows that the notion "emissions into the environment" within the meaning of Art. 6(1) sentence 1 Aarhus Regulation is - contrary to the Court's view - not "clear" and cannot be understood from its wording alone. Rather, the notion is an uncertain legal term that needs to be interpreted.

As already stated in a)-c) above, the provisions of sectoral laws on the protection of specific commercial and industrial secrets and the Charter on Fundamental Rights and the TRIPS Agreement require a restrictive interpretation of the notion "emissions into the environment" within the meaning of Art. 6(1) sentence 1 Aarhus Regulation, as far as the application of this provision can at all take effect in the face of sectoral law provisions on the protection of specific information (in this respect see III.4.b) above).

This interpretation is supported by the Implementation Guide to the Aarhus Convention, published by the United Nation Economic Commission for Europe (UNECE) in 2000 (hereinafter: Implementation Guide). In the legal action, the Commission rightly invoked this Implementation Guide, which on page 60 for interpreting the term emission refers to the definition of the IPPC Directive 96/61/EC, i.e. to the direct or indirect release of substances from installations. ${ }^{30}$

The Court rightly points out that this Implementation Guide cannot bindingly interpret the Aarhus Convention. On the other hand, the General Court in its decision $\mathrm{T}_{33} 8 / 08$ did in fact invoke the Implementation Guide for interpreting the Convention. ${ }^{31}$ At least, the Implementation Guide clearly points out that in 2000 , i.e. a short time after the Convention was enacted, the necessity of disclosing information on substances actually released into the environment without any consideration to commercial and industrial secrets was seen only with respect to emissions from industrial installations. At that time, nobody thought of emissions from the use of substances or preparations.

Against this background, the ruling of German courts cited in III.2 above concludes that the notion "emissions into the environment" is to be interpreted restrictively and refers only to the release of substances from industrial installations. Also the practice of authorities in processing applications for access to (environmental) information in dossiers for registration and authorisation procedures of substance law was based on the Implementation Guide, as also reflected in the Commission's position in the case decided by the Court.

The Implementation Guide, however, is significant not only because of its reference to installations - it also clarifies that the term emission relates to "the [...] direct or indirect release of substances [...] into the air, the water or the soil". This is referred to also by the Advocate General Ms. Kokott who rejects the installation reference of the Implementation Guide and thus principally opens the irrebuttable presumption of Art. 6(1) sentence 1 Aarhus Regulation also, for example, for the use of plant protection products. $^{32}$

According thereto, "information on emissions" within the meaning of Art. 6(1) sentence 1 Aarhus Regulation do not extend to information on substances which are released into the environment at any point of time during their life cycle. Rather, this relates to information on the release of substances as such. ${ }^{33}$ As outlined in III.2 above, the Advocate General therefore in Case C-524/og has in fact classified information that can be connected to emissions only indirectly as "environmental information", but not as information on "emissions into the environment" ${ }^{\prime 34}$. If Art. 6(1) sentence 1 Aarhus Regulation or Art. 4(2) sentence 4 of Directive 2003/04 also covered indirect information on emissions, the scope of application of the exceptions excluded under these provisions, and thus in particular the protection of commercial and industrial secrets, would be very severely limited. ${ }^{35}$ The Advocate General states: "The argu-

30 The IPPC Directive was replaced by the IED Directive of 24 Nov. 2010 and defines emission as "direct or indirect release of substances, vibrations, heat or noise from individual or diffuse sources in the installation into air, water or land".

31 More details in Garcon, The Aarhus Rights in the EU: Internal Review and Access to Justice, StoffR 2012 p. 134 et seq.

32 Opinion in Case C-266/09 paragraph 91.

33 Opinion in Case C-266/09 paragraph 93. Thus also Garcon, loc. cit. EurUP 2012 p. 100 (108)

34 The Advocate General holds that information on trading with emission rights is only indirect information on emissions, because the trading takes place before substances are released.

35 Opinion in Case C-524/09 paragraph 69-74. 
ments made in the Implementation Guide for the Aarhus Convention are therefore more persuasive. It states that the protection of commercial confidentiality should end when the substances to which the confidential information relates are released. Emissions allowance trading, on the other hand, takes place before substances are released. Information on such trading consequently does not constitute information on emissions." ${ }^{36}$

The General Court did not deal with this important point, incorrectly classified the wording of Art. 6(1) sentence 1 Aarhus Regulation as "clear provision of a European Union regulation", moreover with the formulation "relates in a sufficiently direct manner to emissions into the environment" - shifted the extremely important dividing line between indirect and direct information on emissions in an impermissible manner in favour of direct information on emissions, and thus declared information whose disclosure is the subject matter of Case T-545/11 to be direct information on emissions.

The approach by the General Court is to be rejected. It is already questionable whether the dividing line between direct and indirect information on emissions as drawn by the Advocate General Ms. Kokott sufficiently considers the exceptional nature of the provision of Art. 6(1) sentence 1 Aarhus Regulation in substance law. This is much easier with regard to installation-related emissions, as these are released from the installations through chimneys, disposal pipelines and the like. That is why the installation reference in the Implementation Guide does make sense. Upon application in substance law, one easily runs the risk of classifying the entire use of chemicals as emission. The Court's judgment of 08 October 2013 demonstrates that risk. In any case, however, it cannot be right to even more blur the dividing line between direct and indirect information on emissions drawn by Advocate General Kokott by pulling large blocks of information in registration and authorisation procedures into the area of application of the irrebuttable presumption of Art. 6(1) sentence 1 Aarhus Regulation by using the formulation "relates in a sufficiently direct manner to emissions into the environment".

36 Opinion in Case C-524/09 paragraph 74.

37 The short version of the Dossier is published according to Art. 10 Regulation $1107 / 09$. There, information on the relevant impurities cannot be kept secret.

\section{Details on the information contained in the "document at issue"}

\section{a) Identity and quantity of all the impurities in the active substance notified by each operator}

The Court considered information on the identity and quantity of all the impurities in the active substance notified by each operator as "information relating to emissions into the environment", because it "relates in a sufficiently direct manner to emissions into the environment". Therefore, the Court ordered the Commission to disclose this information.

Information on impurities in active substances enjoy special protection under Art. 63(2) lit. b of Regulation 1107/2009. According to Art. 4(2) Transparency Regulation, which according to Art. 3 Aarhus Regulation also applies in the case of "environmental information", they may be disclosed only if there is an overriding public interest in disclosure. However, information on impurities considered to be toxicologically, ecotoxicologically or environmentally relevant are anyway publicly accessible according to Art. 63(2) lit. b of Regulation $1107 / 2009^{37}$. The special protection thus relates to information on impurities that are not considered to be toxicologically, ecotoxicologically or environmentally relevant. The legislator of Regulation 1107/2009 stipulated this protection in knowledge of the Aarhus legislation. Permitting an interpretation of the notion "emissions into the environment" that goes directly against the protection intended by the legislator of Regulation 1107/2009 would be absurd. Therefore, Art. 63(2) lit. b of Regulation 1107/09 is lex specialis towards the general provision of Art. 6(1) sentence 1 Aarhus Regulation. Reference is made to the reasons stated in III.4. $b$.

The ruling of German courts described in III.2 above starts from a different angle but arrives at the same result. According thereto, the uncertain legal notion "emissions into the environment" in Art. 4(2) sentence 4 Directive 2003/4 (identical to Art. 6(1) sentence 1 Aarhus Regulation) is to be interpreted not only according to its wording, but with reference to the "Implementation Guide" on the Aarhus Convention, which limits the notion "emissions into the environment" to emissions from industrial installations. According thereto, Art. 4(2) sentence 4 Directive 2003/4 (identical to Art. 6(1) sentence 1 Aarhus Regulation) is not applicable in substance law. According to this legal view, the protection of commer- 
cial and industrial secrets is subject to an overriding public interest in disclosure, but is not at risk to be entirely eliminated.

However, even if ignoring the notion's reference to installations, as done by Advocate General Kokott in Case C-266/09 and Case C-524/09, the view held by the Court is unfounded in consideration of the explanations in III.4 above. The notion is to be interpreted restrictively, because any intervention in legal interests protected by primary law - which undisputedly includes commercial and industrial secrets - requires specific justification. As outlined in more detail in III.4 $\mathrm{d}$ above, "information [...] on emissions" within the meaning of the definition of "environmental information" in the Aarhus Regulation is not equal to "[...] information relating to emissions into the environment" within the meaning of Art. 6(1) sentence 1 Aarhus Regulation. There is a "quality leap" between the two notions which cannot be explained by considering the wording alone. Insofar, the Court has to be contradicted when it classifies the wording of Art. 6(1) sentence 1 Aarhus Regulation as "clear provision of a European Union regulation" (paragraph 44).

The Court refused a restricted interpretation of the notion "emissions into the environment" and states that information on impurities in the active substance "relates in a sufficiently direct manner to emissions into the environment" because the active substance was included in plant protection products primarily released by spraying into the air.

As outlined in more detail in III.4 $\mathrm{d}$ above, the formulation "relates in a sufficiently direct manner to emissions into the environment" unduly blurs the extremely important dividing line between indirect and direct information on emissions. As demonstrated by the judgment of the Court, this formulation is meant to draw over large blocks of information in registration and authorisation procedures into the area of application of the irrebuttable presumption of Art. 6(1) sentence 1 Aarhus Regulation. This de facto results in an unjustifiable limitation of the protection of commercial and industrial secrets under primary law.

Therefore, "information on the identity and quantity of all the impurities in the active substance notified by each operator", which in a procedure for authorising plant protection products are submitted before the use of these substances, can be indirectly linked to emissions, but it is not information on released substances and do not fall under the irrebut- table presumption of Art. 6(1) sentence 1 Aarhus Regulation, as also confirmed by Art. 63(2) lit. b Regulation 1107/2009.

b) The impurities present in the various batches and the minimum, median and maximum quantities of each of those impurities

The Court considered information on impurities present in the various batches and the minimum, median and maximum quantities of each of those impurities as "information relating to emissions into the environment", because it "relates in a sufficiently direct manner to emissions into the environment". Therefore, the Court ordered the Commission to disclose this information.

The explanations under a) on the impurities in active substances also apply in respect of the impurities in the different batches. According to Art. 63(2) lit. b Regulation 1107/2009, "results of production batches of the active substance including impurities" are specifically protected. This provision is, as set forth in III.4 b in more detail, lex specialis towards Art. 6(1) sentence 1 Aarhus Regulation.

In addition, information on batches of active substances and their impurities which is submitted in an authorisation procedure for plant protection products before these substances are used, does not relate to releases upon the use of plant protection products. Even if - as by Advocate General Kokott - the application of Art. 6(1) sentence 1 Aarhus Regulation is removed from the reference to installations, such information can at best be indirectly related to emissions, but is just not information on released substances. The formulation of the Court "sufficiently direct" blurs this dividing line and results in a no longer justifiable limitation of the protection of commercial and industrial secrets - which in this case is even specifically provided for by law (Art. 63(2) lit. c Regulation 1107/2009).

c) The composition of the plant protection products developed by the operators (on the basis of the active substance)

The Court considered information on the composition of the plant protection products developed by the enterprises as "information relating to emissions into the environment", because it "relates in a sufficiently direct manner to emissions into the environ- 
ment". Therefore, the Court ordered the Commission to disclose this information.

The explanations under a) on the impurities in active substances also apply in respect of the composition of the plant protection products developed by the enterprises. According to Art. 63(2) lit. f Regulation 1107/2009, "information on the complete composition of a plant protection product" are specifically protected. This provision is, as set forth in III. $4 \mathrm{~b}$ in more detail, lex specialis towards Art. 6(1) sentence 1 Aarhus Regulation.

In addition, information on the complete composition of a plant protection product which is submitted in an authorisation procedure for plant protection products before these substances are used does not relate to releases in case of the use of plant protection products. Even if - as by Advocate General Kokott - the application of Art. 6(1) sentence 1 Aarhus Regulation is removed from the reference to installations such information can at best be indirectly related to emissions, but does just not constitute information on released substances. The formulation of the EU Court "sufficiently direct" blurs this dividing line and results in a no longer justifiable limitation of the protection of commercial and industrial secrets - which in this case is even specifically provided for by law (Art. 63(2) lit. f Regulation 1107/2009).

\section{Summary}

As far as is known, the decision of the General Court of 08 October 2013 was the first time that a European Court applied the irrebuttable presumption of Art. 6(1) sentence 1 Aarhus Regulation and Art. 4(2) sentence 4 of Directive 2003/4 in the area of substance law.

Thus far, European courts avoided dealing more closely with this "sensitive" provision. ${ }^{38}$ The previous practice of the Commission, the European and national authorities ${ }^{39}$ and also of the German courts refused to apply this provision to requests for access to information in the area of substance law. By way of justification, reference was in this respect made to the necessity of a restrictive interpretation of this pro-

\footnotetext{
38 E.g. C-266/09 and C-524/09.

39 E.g. also the ECHA for REACH.

40 In the article, this conclusion is also substantiated by the ECJ's ruling in Case C-524/11 (see III.4 b).
}

vision, since its application absolutely required the disclosure of information which often contains commercial and industrial secrets protected by primary law. Previous practice also considered it necessary to make an interpretation of Art. 6(1) sentence 1 Aarhus Regulation and Art. 4(2) sentence 4 of Directive $2003 / 4$ in conformity to primary law. Also invoked was the Implementation Guide to the Aarhus Convention, published by the United Nation Economic Commission for Europe (UNECE) in 2000 (Implementation Guide), which limited the notion "emissions into the environment" to installation-related emissions, which excludes application to substance law.

The General Court did not accept these arguments. It also denied acceptance of the statutory provisions for the protection of particular information in Art. 63(2) of Plant Protection Regulation 1107/09 and gave priority to the "clear" provision in Art. 6(1) sentence 1 Aarhus Regulation. All the information that the Court ordered the Commission to disclose by using this line of argument is explicitly specified in Art. 63(2) Regulation 1107/09. Contrary to the view held by the Court, the provision of Art. 6(1) sentence 1 Aarhus Regulation can be interpreted only to the effect that Art. 63(2) Regulation 1107/09 remains applicable. This requires that the decisions of the legislator of Regulation 1107/09 are respected. Therefore, Art. 63(2) of Regulation 1107/09 is lex specialis towards the general provision of Art. 6(1) sentence 1 Aarhus Regulation, with the result that the irrebuttable presumption does not apply to the information specified therein. ${ }^{40}$ As a consequence of the reservation of the Aarhus legislation in Art. 63(3) Regulation 1107/09, the European Union's institutions deny disclosure of the information specified in Art. 63(2) Regulation 1107/09 according to Art. 3 Aarhus Regulation in conjunction with Art. 4(2) Transparency Regulation, unless there is an overriding public interest in the disclosure. This already constitutes a clear limitation of the protection of the information according to Art. 63(2) Regulation 1107/2009. The irrebuttable presumption of Art. 6(1) sentence 1 Aarhus Regulation can, however, not refer to the information specified in Art. 63(2) Regulation 1107/09.

The aforementioned Implementation Guide is not only important for the interpretation of the irrebuttable presumption of Art. 6(1) sentence 1 Aarhus Regulation and Art. 4(2) sentence 4 of Directive 2003/4 due to its reference to installations. It also clearly 
points out that the term emission refers to "the $[. .$. direct or indirect release of substances [...] into the air, the water or the soil". According thereto, the protection of commercial secrets shall end when those substances are released to which the information that was kept secret refers. As outlined in more detail in III.4 d above, "information [...] on emissions" within the meaning of the definition of "environmental information" in the Aarhus Regulation is not equal to "[...] information relating to emissions into the environment" within the meaning of Art. 6(1) sentence 1 Aarhus Regulation. There is a "quality leap" between the two notions which cannot be explained by considering the wording alone and which precludes uniform interpretation. The Advocate General Ms. Kokott clearly worked this out in her opinion in Case C-524/11 and concluded that information that can be related to emissions only indirectly could, while being "environmental information", not make the "quality leap" to the irrebuttable presumption under Art. 6(1) sentence 1 Aarhus Regulation. The Advocate General then established that the trading with emission rights took place before substances were released. While information thereon was "environmental information, it was not "information on emissions."

The General Court did not deal with this important point, incorrectly classified the wording of Art. 6(1) sentence 1 Aarhus Regulation as "clear provision of a European Union regulation", moreover with the formulation "relates in a sufficiently direct manner to emissions into the environment" - shifted the extremely important dividing line between indirect and direct information on emissions in an impermissible manner in favour of direct information on emissions, and thus declared information whose disclosure is the subject matter of Case T-545/11 to be direct information on emissions.

The approach by the Court is to be rejected. It is already questionable whether the dividing line between direct and indirect information on emissions as drawn by the Advocate General Ms. Kokott sufficiently considers the exceptional nature of the provision of Art. 6(1) sentence 1 Aarhus Regulation in substance law. This is much easier with regard to installation-related emissions, as these are released from the installations through chimneys, disposal pipelines and the like. That is why the installation reference in the Implementation Guide does make sense. Upon application in substance law, one easily runs the risk of classifying the entire use of chemicals as emission. The Court's judgment of o8 October 2013 demonstrates this risk. In any case, however, it cannot be right to even more blur the dividing line between direct and indirect information on emissions drawn by Advocate General Kokott by pulling large blocks of information in registration and authorisation procedures into the area of application of the irrebuttable presumption of Art. 6(1) sentence 1 Aarhus Regulation by using the formulation "relates in a sufficiently direct manner to emissions into the environment".

The Court's decision in Case T-545/11 relates to plant protection law. It does, however, have implications on the entire area of substance law. All other substance laws also contain provisions for the protection of commercial and industrial secrets which would be obsolete if the Court's decision were to become unappealable. The Court's interpretation of Art. 6(1) sentence 1 of the Aarhus Regulation 1367/2006 fundamentally changes the previous legal practice of the authorities on public access to information submitted to them in the course of registration and authorisation procedures, which frequently contain commercial and industrial secrets. It thus affects fundamental issues. Therefore, it would be desirable that the ECJ clarified these issues.

At the time this article was written (early November 2013) it had still been open whether the Commission or any other party entitled to appeal would file an appeal against the General Court's judgment. If the EU Court's judgment became unappealable, the balance which the Union legislature ensured in the substance law provisions (plant protection law, biocide law, REACH, etc.) between the obligation on undertakings to communicate possibly sensitive commercial information to the authorities on the one hand, and the guarantee of increased protection of the information within the scope of professional and business secrecy on the other hand would be considerably impaired. Rectifications by the legislator - also with regard to the Aarhus legislation (Aarhus Regulation, Directive 2003/4) - might then become necessary. 